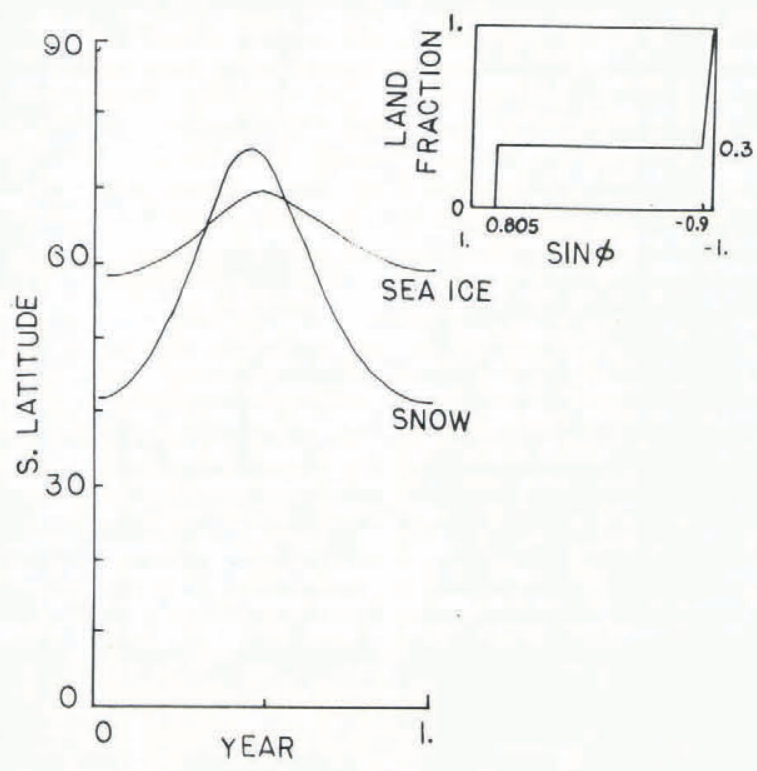

Fig.6. Snowline extent in the southern hemisphere as generated by the model.

land mass near the South Pole was too large to permit snow to remain on the ground for the entire year.

Shifting continentatl distributions must surely have been accompanied by changes in the circulation of the ocean, and, therefore, changes in the poleward advection of heat (Kvasov and Verbitsky 1981). In its present form, our model cannot account for this. It is certainly an important effect, and we are now modifying our model in such a way that we can include it. It seems clear that one result of including an increased poleward advective heat flux by the oceans, as suggested by Frakes and Kemp (1973), will be to increase the annual average temperature on the continent near the South Pole. This is consistent with the belief that polar climates were warmer during the Cretaceous.

Finally, we emphasize our main point. While a land mass must be close to a pole in order for an ice sheet to form (Watts and Hayder 1983, in press, Oerlemans in press) it seems possible for the land mass to be too large. (This is probably why the North American ice sheet formed before the Scandinavian ice sheet during the Quaternary ice age.) We conclude that a realistic model with which to study the initial formation of the Antarctic ice sheet 30 to $50 \mathrm{Ma}$ BP should contain a land-sea distribution and a seasonal cycle, as well as realistic poleward advection by ocean currents.

\section{ACKNOWLEDGEMENT}

We acknowledge support by the US National Science Foundation under grant ATM-7916332.

\section{REFERENCES}

Beaty B 1978 The causes of glaciation. American Scientist 66(4): 452-459

Frakes L A, Kemp E M 1973 Palaeogene continental positions and evolution of climate. In Tarling D H, Runcorn S K (eds) Implications of continental drift to the earth sciences. Vol 1: 539-559

Hayder ME Unpublished A two-dimensional, seasonal, energy balance climate model with continents and ice sheets: testing the Milankovitch theory of ice ages. (MS thesis, Tulane University, 1982)

Kukla G J 1978 Recent changes in snow and ice. In Gribbin J (ed) Climatic change. Cambridge etc, Cambridge University Press: 114-129

Kvasov D D, Verbitsky M Ya 1981 Causes of Antarctic glaciation in the Cenozoic. Quaternary Research 15(1): $1-17$

Oerlemans $\mathrm{J}$ In press On the origins of the ice ages. In Berger $A$, Imbrie J, Hays J, Kukla G, Saltzman B (eds) Milankovitch and climate: understanding the response to orbital forcing. Dordrecht, Reidel Pubilishing Co.

Watts R G, Hayder ME 1983 The origin of the 100kiloyear ice sheet cycle in the Pleistocene. Journal of Geophysical Research 88(9): 5163-5166

Watts R G, Hayder ME In press A two-dimensional, seasonal, energy-balance climate model with continents and ice sheets: testing the Milankovitch theory. Tellus

\title{
A GLOBAL PALEOCLIMATIC DATABASE FOR 6 AND 9 ka BP
}

\section{(Abstract)}

by

\section{Thompson Webb III}

(Department of Geological Sciences, Brown University, Providence, Rhode Island 02912-1846, U.S.A.)

A Cooperative Holocene Mapping Project (COHMAP) has assembled a database of Holocene paleoclimatic data from 1000 locations with ${ }^{14} \mathrm{C}$ dates (Table I). The data are stored on computer tapes at Brown University and will be available for verification of computer simulations of Holocene climates. Pollen, lake-level, and marine plankton data are the main sources of paleoclimatic information (Webb in press). Multivariate statistical techniques (Imbrie and Kipp 1971, Webb and Bryson 1972) and energy-budget models (Kutzbach 1980) exist that can transform each of these types of data into quantitative estimates of past temperature and precipitation.

Sites with pollen data are the most numerous ( 750 sites) with in the database (Table I), and dense networks of pollen sites exist in eastern North
America (Bernabo and Webb 1977), Europe (Huntley and Birks 1983), the Soviet Union (Peterson unpubl ished) and Alaska (Anderson unpubl ished). Pollen data from New Zealand, Africa, and South America are also being assembled. Work is now in progress to ga in climatic estimates from this pollen information, and Webb (in press) has presented maps of past temperatures and precipitation in the midwestern United States.

Lake-level data are the next most numerous source of Holocene paleoclimatic data (200 sites). Dense networks of sites exist in western North America, Africa and Australia (Street and Grove 1979). The changing lake levels directly record variations in the local water budget from which energy-budget and hydrological models can estimate past changes in precipitation (Kutzbach 1980). Water levels were 
TABLE I. DISTRIBUTION OF TERRESTRIAL AND MARINE SITES WITH RADIOCARBON-DATED POLLEN, LAKE-LEVEL, AND PLANKTON DATA IN THE COHMAP DATABASE

Region

North America

South America

Europe

USSR

Asia

Africa

Australia, New Zealand,

Oceania

$$
\text { Pollen }
$$

Lakes

Total

Total 750

400
20
250
35
15
10

1

30

90

200

Atlantic Ocean

Pacif ic Ocean

Indian Ocean

Southern Ocean

Marginal seas

\begin{tabular}{cr} 
& 25 \\
& 8 \\
& 10 \\
& 4 \\
& 3 \\
\hline & \\
\hline & 50
\end{tabular}

high in many African and north-west Indian lakes at 9 and $6 \mathrm{ka} \mathrm{BP}$, and the model calculations indicate that the rainfall in Chad and north-west India was about $200 \mathrm{~mm}$ higher at $6 \mathrm{ka}$ BP than at present (Kutzbach 1980, Swain and others 1983).

Marine plankton data are mainly available from the Atlantic and western Indian oceans (Ruddiman and McIntyre 1981, Prell in press). For most of the ocean regions, sedimentation rates are too low for deep-sea cores to resolve differences with in the Holocene. Isolated samples from the Southern Ocean, from the margins of the Pacific Ocean, and from several marginal seas fill out the network of marine data. Patterns are evident in the maps of oceansurface temperatures estimated from these data for $6 \mathrm{ka} \mathrm{BP}$, but most temperatures are similar to those for today.

Recent climate-model simulations have shown how important Milankovitch factors are in influencing the global climatic patters at $9 \mathrm{ka}$ BP (Kutzbach 1981). The model simulations for rainfall in the subtropics agree well with the paleoclimatic data for high lake levels in this region at $9 \mathrm{ka} \mathrm{BP}$ (Street and Grove 1979, Prell in press). The presence of the Laurentide ice sheet also affects the simulated climatic patterns at $9 \mathrm{ka}$ BP (Kutzbach and 0tto-Bliesner 1982). At $6 \mathrm{ka}$ BP the extent of terrestrial ice sheets is approximately similar to the ice extent today, but summer insolation in the northern hemisphere was about $5 \%$ larger than it is today. The patterns of pollen-derived temperature estimates for eastern North America and Europe agree well with initial model results for July temperatures at $6 \mathrm{ka}$ BP. These comparisons between model results and the paleoclimatic data will be a continuing focus for COHMAP research.

\section{ACKNOWLEDGEMENTS}

COHMAP research is supported at Brown University by the National Science Foundation Climate Dynamics Program (ATM81-11897.) and a contract (DE-AC0279EV10079) from the US Department of Energy Carbon
Dioxide Research Division. I thank P M Anderson, H J B Birks, P A and H R Delcourt, S Harrison, B Huntley, V Markgraf, R Marvil, J H McAndrews, M McGlone, F A Perrott, G M Peterson, W L Preli, J C Ritchie, W F Ruddiman, J Salinger, S K Short and $H E$ Wright Jr for help in assembling the global database. R Arigo, R Mellor and S Suter provided

technical assistance.

\section{REFERENCES}

Anderson P M Unpublished Reconstructing the past: the synthes is of archeological and palynological data, northern Alaska and northwestern Canada. (PhD thesis, Brown University, 1982)

Bernabo J C, Webb T III 1977 Changing patterns in the Holocene pollen record of northeastern North America: a mapped summary. Quaternary Research 8(1): 64-96

Huntley B, Birks, H J B 1983 An atlas of past and present pollen maps for Europe. Cambridge, Cambridge University Press

Imbrie, J, Kipp N G 1971 A new micropaleontological method for quantitative paleoclimatology: application to a late Pleistocene Caribbean core. In Turekian K K (ed) The late Cenozoic glacial ages. New Haven and London, Yale University Press: 71-181

Kutzbach J E 1980 Estimates of past cl imate at paleolake Chad, North Africa, based on a hydrological and energy-balance model. Quaternary Research 14(2): 210-223

Kutzbach J E 1981 Monsoon climate of the early Holocene: climate experiment with the Earth's orbital parameters for 9000 years ago. Science 214 (4516): 59-61

Kutzbach J E, Otto-Bliesner B L 1982 The sensitivity of the African-Asian monsoonal climate to orbital parameter changes for 9000 years B.P. in a lowresolution general circulation model. Journal of the Atmospheric Sciences 39(6): 1177-1188

Peterson, GM Unpublished Holocene vegetation and cl imate in the western IJSSR. (PhD thes is, University of Wiscons in-Madison, 1983)

Prell W L In press Monsoonal climate of the Arabian Sea during the late Quaternary: a response to changing solar radiation. In Hansen J, Takahash $i \mathrm{~T}$ (eds) Climate processes: sensitivity to solar irradiance and $\mathrm{CO}_{2}$. Washington, DC, American Geophysical Union (M Ewing Series 4)

Ruddiman W F, McIntyre A 1981 The North Atlantic ocean during the last deglaciation. Palaeogeography, Palaeoclimatology, Palaeoecology 35: 145-

Street F A, Grove A T 1979 Global maps of lakelevel fluctuations since 30,000 yr BP. Quaternary Research 12(1): 83-118

Swa in A M, Kutzbach J E, Hastenrath S 1983 Estimates of Holocene precipitation Rajasthan, India, based on pollen and lake-level data. Quaternary Research 19(1): 1-17

Webb T III In press Pollen analys is and paleocl imatology. In Hecht A D (ed) Paleoclimate data analysis and modeling. New York, John Wiley and Sons

Webb T III, Bryson R A 1972 Late- and postglacial cl imatic change in the northern midwest, USA: quantitative estimates derived from fossil pollen spectra by multivariate statistical analys is. Quaternary Research 2(1): 70-115 